\title{
PENATAAN ELEMEN STRUKTURAL UNTUK MENYEDERHANAKAN PERILAKU DINAMIK, DALAM KETERPADUAN DENGAN DESAIN ARSITEKTUR
}

\author{
Bisatya W. Maer, Benjamin Lumantarna, Joyce M. Laurens \\ Fakultas Teknik Sipil dan Perencanaan, Universitas Kristen Petra Surabaya \\ Email:mbm@petra.ac.id
}

\begin{abstract}
ABSTRAK
Penelitian ini bertujuan untuk menemukan penataan elemen struktural yang dapat lebih efektif menyederhanakan perilaku dinamik struktur terhadap gempa bumi, dan tidak merusak keterpaduan antara rancangan arsitektural dengan rancangan struktural. Sebagai studi kasus digunakan prototipe yang merupakan bagian tower dari Gedung Intiland Tower Jakarta. Penelitian diawali dengan membuat dan menganalisis model eksisting dan tiga buah model perubahan tata letak elemen struktural untuk mendapatkan perbandingan defleksi lateral dari model-model tersebut. Perbandingan tersebut menunjukkan tingkat efektifitas tata letak elemen struktural dalam menyederhanakan perilaku dinamik, sementara pengaruhnya terhadap tingkat keterpaduan dievaluasi dengan metode diskriptif. Hasil penelitian menunjukkan bahwa ada dua model eksperimen yang signifikan mengurangi defleksi lateral dan satu diantaranya tidak mengganggu keterpaduan rancangan arsitektural.
\end{abstract}

Kata kunci: Tata letak elemen struktural, keterpaduan, struktur, desain arsitektur.

\begin{abstract}
This research is aimed to obtain the structural element's layout to simplify the dynamic behavior against earthquake without disturbing the integration between architectural design and structural design. As a case study a prototype tall building which is the tower part of Intiland Tower, Jakarta is considered Research is started by making and analyzing existing models and three rearranged structural elements layout models to obtain the lateral deflection comparisons of those models. The comparisons show the effectiveness of structural layout in simplifying the dynamic behavior, while its influences toward the integrity level with architectural design is evaluated using descriptive method. The results show that the two experiment models could minimize lateral deflection quite significantly, one of which does not disturb the integrity of the architectural design.
\end{abstract}

Keywords: Structural element layout, integration, structure, architectural design.

\section{PENDAHULUAN}

Problem umum perancangan arsitektur bangunan dalam hubungannya dengan perancangan struktur adalah perbedaan kemauan arsitek dengan perancang struktur. Menurut Wangsadinata (1986) sebagai perancang struktur Gedung Intiland Tower Jakarta (GITJ) yang digunakan sebagai sudi kasus dalam penelitian ini, kemauan arsitek dan perancang struktur telah terakomodasi dengan baik, karena arsitek dan perancang struktur berangkat dari pendekatan perancangan yang sama, yaitu: ruang, bentuk dan struktur dikembangkan secara terpadu. Bila dilihat dari wujud bangunan yang ada, nampak sekali bahwa arsitek bangunan GITJ mempunyai keleluasaan yang luas dalam menuangkan ide-idenya (Gambar 1), sehingga menghasilkan bentuk bangunan tinggi yang unik dan kompleks. Ditinjau dari teori Arnold (1982) kompleksitas bentuk bangunan tersebut termasuk dalam "konfigurasi" yang tidak beraturan terhadap gempa bumi. "Konfigurasi" bangunan tidak beraturan dapat mengakibatkan perilaku dinamik struktur terhadap gempa menjadi kompleks. Penulis tertarik untuk melakukan penelitian perilaku struktur bangunan GITJ dengan fokus hanya pada towernya saja, maka bentuk asli bangunan GITJ dimodifikasi dengan menghilangkan sayap-sayap podium (Gambar 1). Karena karya arsitektur merupakan kesatuan yang utuh, maka dalam pembahasan keterpaduan struktur dengan desain arsitektur tetap ditinjau seluruh bangunan, dengan asumsi tidak ada perubahan tata letak arsitektural eksisting.

Penulis melihat ada peluang untuk merancang tata letak elemen struktural yang lebih efektif untuk menyederhanakan perilaku dinamik struktur GITJ yang dimodifikasi (GITJ-M) dengan tidak merubah karakter tampilan arsitektur tower nya. Bertolak dari hal tersebut, rumusan masalah dalam penelitian ini adalah: 
- Bagaimana pola tata letak elemen struktural pada bangunan GITJ-M yang dapat lebih menyederhanakan perilaku dinamik akibat gempa bumi.

- Bagaimana pengaruh perubahan tata letak elemen struktural pada bangunan GTIJ-M terhadap keterpaduan rancangan arsitektur dan struktur?

Untuk menguji efektifitas penataan elemen struktural, dibuat model-model eksperimen perubahan tata letak elemen-elemen struktural yang seminimal mungkin mengakibatkan perubahan karakter tampilan arsitekturnya, yaitu dengan menempatkan elemenelemen struktural sedapat mungkin pada posisi yang sudah ada dindingnya. Efektifitas tersebut diukur dari perbandingan antara besarnya defleksi lateral maksimal yang terjadi pada model eksisting dibandingkan dengan yang terjadi pada model-model eksperimen. Sedangkan keterpaduan perancangan arsitektur dievaluasi dengan metode diskriptif.

\section{RANCANGAN ARSITEKTUR GEDUNG INTILAND TOWER JAKARTA}

Bangunan GITJ (dahulu bernama Wisma Dharmala Sakti) berlokasi di jalan Sudirman 32, Jakarta, merupakan bangunan kantor pusat PT. Intiland. Di dalamnya terdapat juga perkantoran sewa serta sejumlah fasilitas pelengkap seperti bank dan restoran. Gedung ini dirancang pada tahun 1982 oleh Paul Rudolph (USA) sebagai perancang arsitektur, dan PT. Wiratman \& Rekan (Jakarta) sebagai perancang struktur. GITJ merupakan bangunan tower 27 lantai, dengan ketinggian 112,20 m, terdiri atas lantai tipikal (20 lantai), lantai podium (7 lantai) dengan total luas lantai sebesar $45.260 \mathrm{~m}^{2}$.

Untuk dapat mempertahankan keterpaduan rancangan arsitektur dan struktur, perlu diidentifikasi keunikan ekspresi asitektur GITJ. Keunikan tersebut dapat diidentifikasi melalui perbandingan rancangan GITJ dengan karya-karya Paul Rudolph yang lain. Karya pembanding dipilih berdasarkan:

- Kurun waktu perancangannya berdekatan dengan waktu perancangan GITJ, dengan asumsi gaya perancangan Paul Rudolph tidak mengalami perubahan.

- Fungsi bangunan sejenis.

- Bangunan berada di negara dengan rumpun budaya yang sama.

- Lokasi berada dilingkungan yang sejenis.

Dipilih Concourse Building di Singapura (CBS) dan Bond Centre di Hongkong (BCH). Waktu perancangan GITJ adalah tahun 1982, Concource Building tahun1981, dan Bond Centre tahun1984. Fungsi se- bagian besar ketiga bangunan tersebut adalah perkantoran, berada di lingkungan pusat perdangangan yang sibuk, dan berada di benua Asia (Gambar 2,3,4).

Dari studi perbandingan ini, dapat diidentifikasikan ada beberapa kesamaan ekspresi eksterior yang unik dan selalu ada pada ketiga rancangan Paul Rudolph, sehingga penulis menyimpulkannya sebagai keunikan rancangan GITJ. Kesimpulan ini akan dirangkum dalam pembahasan selanjutnya.

Selain dari studi perbandingan, keunikan ekspresi bangunan lebih jauh diidentifikasi melalui pengamatan di tempat, terutama di dalam interior bangunan dan dari gambar-gambar rancangan GITJ. Hasilnya menunjukkan bahwa ekspresi arsitektur yang menonjol adalah skala dan kontinuitas ruang. Skala ruang diiden-tifikasi dari ukuran tinggi dan luas ruang-ruang, sedangkan kontinuitas ruang diidentifikasi dari spatial interpenetration antar ruang-ruang (Gambar 5, 6, 7).

Dari kajian tersebut, dapat disimpulkan keunikan ekspresi rancangan GITJ sebagai berikut:

- Skala ruang manusiawi pada lingkungan terbentuk karena adanya atrium terbuka yang diorientasikan ke arah trotoir jalan raya, dan dibentuk oleh massa podium. Atrium terbuka tersebut berfungsi sebagai ruang penerima atau ruang transisi dari lingkungan luar bangunan menuju ke bangunan.

- Hirarki ruang terbentuk dari susunan ruang yang mempunyai perbedaan dimensi (luas dan tinggi).

- Kolom-kolom ganda ditonjolkan dari lantai dasar sampai ke puncak. Di bagian podium, kolomkolom ganda berukuran sangat langsing dan panjang menembus atrium terbuka.

- Tampak bangunan secara visual terbagi menjadi dua kelompok, yaitu bagian tipikal dan bagian podium. Bagian tipikal terdiri dari tiga bentuk denah yang disusun membentuk sebuah unit, dan unit-unit tersebut disusun ke atas secara repetitif.

- Spatial interpenetration menghasilkan hubungan ruang yang kontinu secara horisontal dan vertikal.

Kesimpulan tentang keunikan ekspresi bangunan GTIJ tersebut di atas akan menjadi acuan dalam pembuatan model eksperimen. Perubahan tata letak elemen struktural diusahakan agar semaksimal mungkin tidak mengubah keunikan ekspresi tersebut. Untuk itu hal-hal yang harus dipertahankan adalah:

- Keterbukaan atrium diorientasikan ke arah trotoir, sehingga tidak boleh ada penghalang tambahan pada bagian depan bangunan.

- Skala ruang.

- Pengelompokkan dan repetisi pada tampak.

- Kontinuitas ruang.

- Kelangsingan kolom-kolom ganda. 


\section{PEMAHAMAN "KONFIGURASI" BANGUNAN}

Gempa merupakan beban dinamik yang pengaruhnya terhadap bangunan lebih dominan pada arah lateral dibandingkan pada arah vertikal. Arnold (1982), mengelompokkan elemen struktural pendukung gaya lateral menjadi tiga, yaitu: Cantilever Wall, Braced Frame, Moment-resisting Frame. Disamping tiga elemen tersebut ada bidang diafragma horisontal yang meratakan beban-beban lateral agar dapat mencapai masing-masing elemen penahan gaya lateral. Elemen-elemen struktural penahan gaya lateral tersebut bersama dengan tata ruang dan bentuk bangunan serta elemen-elemen non-struktural, secara keseluruhan membentuk "konfigurasi bangunan" yang mencakup: bentuk/proporsi/ukuran bangunan; tata letak elemen-elemen struktural; tata letak elemenelemen non struktural.

Perilaku struktur akibat konfigurasi bangunan yang tidak beraturan dijelaskan dengan teori Arnold ${ }^{1}$ dan Charleson ${ }^{3}$ :

1. Torsi:

Torsi terjadi karena pusat massa (centre of mass $=$ CoM) bangunan tidak berimpit dengan pusat perlawanan lateral (lateral resistant) atau pusat rotasi (centre of rotation $=\mathrm{CoR}$ ). Posisi CoM dipengaruhi oleh penyebaran beban mati dan beban hidup dalam denah tiap-tiap lantai, sedangkan posisi CoR dipengaruhi oleh tata letak elemen-elemen struktural penahan gaya lateral. Beban gempa bekerja di CoM, sedangkan resultan perlawanan struktur bekerja di CoR. Apabila CoM dan CoR tidak berimpit terjadi torsi pada denah bangunan (Gambar 8).

2. Soft storey

Soft storey merupakan problem struktural yang disebabkan oleh diskontinuitas kekuatan dan kekakuan struktur yang signifikan bila ditinjau pada penampang vertikal bangunan (Gambar 9), dimana terdapat satu tingkat/lebih yang sangat lemah (atau lebih fleksibel, menurut Charleson, 2008) dibandingkan dengan tingkat-tingkat yang di atasnya. Ciri-ciri dari konfigurasi ini adalah salah satu atau beberapa tingkat (pada umumnya lantai dasar) mempunyai ukuran lebih tinggi dibandingkan dengan tingkat-tingkat di atasnya, atau bentang baloknya lebih lebar dari tingkattingkat diatasnya, sehingga kekakuan struktur pada tingkat ini jauh lebih kecil.

\section{IDENTIFIKASI MASALAH "KONFIGURASI" BANGUNAN GITJ-M}

Identifikasi didasarkan definisi Arnold ${ }^{1}$, yaitu berdasarkan bentuk, dimensi, proporsi massa bangun- an, serta tata letak elemen struktural, dan tata letak elemen nonstruktural. Dari segi bentuk (Gambar 10):

- Bentuk garis besar (outline) denah tower cukup beraturan.

- Bentuk denah lantai-lantai podium tidak beraturan, distribusi massa (beban mati dan beban hidup) tidak simetri terhadap struktur pendukung.

- Dimensi void di lantai-lantai podium pada umumnya luas dan bentuknya tidak beraturan, hal ini mengurangi kekakuan bidang diafragma, selain itu mengakibatkan penyebaran beban gravitasi tidak merata dan tidak simetri pada tiap-tiap denah podium.

Dari segi tata letak elemen struktural (Gambar 11):

- Hasil perhitungan dengan software ETABS (2005) memperlihatkan bahwa pada sumbu Y (tegak lurus gempa arah sumbu X), posisi cantilever core jauh dari CoM. Eksentrisitas maksimal sebesar 10,13 m di lantai tipikal 8, dan di podium sebesar 10,01 m di lantai 6 .

- Pada sumbu X (tegak lurus gempa arah sumbu Y), posisi cantilever core di lantai-lantai tipikal relatif simetri, sedangkan di podium terdapat ekesintrisitas karena posisi cantilever core -3 asimetri. Eksentrisitas di lantai tipikal terbesar berada di lantai 7 sebesar $0,30 \mathrm{~m}$, dan di podium eksentrisitas terbesar berada di lantai 4 sebesar 4,65 m.

Kesimpulan "konfigurasi" bangunan:

1. Torsi terjadi karena posisi cantilever core eksentris terhadap CoM, terutama sangat signifikan pada sumbu Y. Dengan demikian torsi terbesar adalah akibat gempa dari arah tegak lurus sumbu Y, yaitu dari arah sumbu $\mathrm{X}$. Sedangkan pada sumbu $\mathrm{X}$ eksentrisitas sangat kecil, maka torsi akibat gempa dari arah sumbu Y tidak signifikan.

2. Soft storey, terjadi karena adanya kolom-kolom ganda yang sangat langsing. Di podium terdapat kolom setinggi $31 \mathrm{~m}$ dengan diameter $1,30 \mathrm{~m}$, jauh lebih langsing dari pada kolom-kolom tipikal diatasnya dengan tinggi $4 \mathrm{~m}$ dengan diameter yang sama (Gambar 10,12,14). Menurut Wangsadinata (1986), rancangan struktur GITJ-M mengantisipasi soft strorey dengan memanfaatkan core -3 setinggi podium sebagai cantilever core, dan merancang semua kolom ganda di podium dengan steel reinforced concrete (komposit).

Dari dua butir kesimpulan di atas, maka masalah torsi adalah yang signifikan terjadi pada struktur GITJ-M dan menjadi fokus penelitian selanjutnya.

\section{PEMODELAN STRUKTUR}

\section{Rancangan Tata Letak Elemen Struktural}

Rancangan tata letak elemen struktural bertolak dari: 
- Batasan dan lingkup pembahasan.

- Rumusan masalah dan kesimpulan dari identifikasi masalah struktural.

- Kesimpulan tentang kekhasan ekspresi arsitektural GITJ.

- Organisasi dan program ruang.

Charleson $^{3}$ menawarkan konsep penyederhanaan perilaku torsi dengan cara meminimalkan eksentrisitas. Penerapan konsep Charleson dalam pembuatan model struktur eksperimen diterapkan dengan memindahkan cantilever core mendekat pada CoM. Agar pemindahan posisi cantilever core tersebut tidak mengubah ekspresi arsitektural yang ada, maka diusahakan untuk:

- memindahkan cantilever core pada dinding non struktural yang sudah ada

- tidak menambahkan cantilever core yang menghalangi keterbukaan atrium ke arah trotoir

- tidak ada penambahan cantilever core yang mengakibatkan terputusnya kontinuitas ruang

- tidak ada penambahan cantilever core pada fasad bangunan

- tidak terjadi perubahan skala yang signifikan akibat penempatan cantilever core; tidak ada penambahan dimensi kolom-kolom ganda

- sedapat mungkin tidak mengubah organisasi dan program ruang.

\section{Model Eksisting (Gambar 13,14)}

Dalam denah eksisting, dinding nonstruktural permanen yang berdiri dari lantai dasar sampai puncak bangunan adalah: dinding-dinding shaft utilitas, dan dinding-dinding tangga -2 yang posisinya berada dekat CoM. Artinya pemindahan posisi cantilever core yang dapat memenuhi tuntutan di atas hanya di daerah sekitar shaft utilitas dan dindingdinding tangga -2 saja.

Ditemukan tiga alternatif tata letak elemen struktural, yaitu: model eksperimen 1, model eksperimen 2, dan model eksperimen 3. Pada model eksperimen 1 di lantai dasar, lantai 5, dan lantai 6 ada perubahan denah di area toilet, yang seharusnya tanpa toilet menjadi ada dinding cantilever core (gambar 14 dan 16). Karena hasil analisis model eksperimen 1 menunjukkan peningkatan kekakuan yang signifikan, maka alternatif ini ditampilkan untuk memperlihatkan ada model yang paling ideal dari segi penataan elemen struktural. Dari sudut pandang keterpaduan antara struktur dengan desain arsitektur, hal ini bermanfaat untuk bahan konsultasi/negosiasi dengan arsitek pada proses desain awal.
Model Eksperimen 1 (Gambar 15,16)

Pada model ini dinding-dinding toilet, dinding core tangga- 2 , dan dinding-dinding tangga -3 setinggi podium dimanfaatkan sebagai cantilever core. Sedangkan struktur core lift -1 diubah menjadi moment resisting frame yang diisi dengan dinding non struktural.

\section{Model Eksperimen 2 (Gambar 17,18)}

Dalam model ini dicoba untuk menghindari penggunaan dinding-dinding toilet sebagai cantilever core. Yang dimanfaatkan sebagai cantilever core pada model ini dinding-dinding core tangga -2, semua shaft toilet, dinding core tangga -3 setinggi podium, dan sebagian lift core -1 yang posisinya paling mendekati pusat denah. Sisa lift core diubah menjadi moment resisting frame yang diisi dengan dinding nonstruktural.

\section{Model Eksperimen 3 (Gambar 19, 20)}

Dalam model ini dicoba untuk tidak memanfaatkan sama sekali lift core sebagai cantilever core, dengan harapan CoR semakin bergeser mendekati CoM pada sumbu Y, tetapi dengan resiko kekakuan core tidak cukup besar untuk mengurangi defleksi lateral. Pada model ini dinding-dinding core tangga -2 dan semua shaft toilet, serta dinding core tangga -3 setinggi podium dimafaatkan sebagai cantilever core.

Model eksisting, model eksperimen 1, 2 dan 3 dianalisis dengan software ETABS v. $9.05^{4}$ dengan masukan yang sama:

- Beban gempa berdasarkan respon spektrum wilayah 3, Jakarta, tanah lunak, menurut SNI 031726-2002,

- Bahan cantilever core dan kolom-kolom untuk semua model sama yaitu dari beton bertulang.

- Dimensi penampang tiap-tiap cantilever core dan tiap kolom-kolom untuk semua model diasumsikan sama dari lantai dasar hingga puncak bangunan.

- Pada model eksisting tebal dinding lift core -1 $=60 \mathrm{~cm}$ dan $65 \mathrm{~cm}$ (Gambar 23); tebal dinding core tangga -2 dan $3=40 \mathrm{~cm}$.

- Pada model eksperimen 1, 2, dan 3 tebal dinding core $-2=40 \mathrm{~cm}$; dinding toilet $=15$ $\mathrm{cm}$, dan dinding core $-3=40 \mathrm{~cm}$, masingmasing core tersebut berfungsi sebagai cantilever core.

- Diameter kolom podium lantai 1 sampai dengan lantai 6 untuk kolom-kolom eksterior $120 \mathrm{~cm}$, kolom-kolom interior $130 \mathrm{~cm}$.

o Diameter kolom lantai-lantai tipikal $120 \mathrm{~cm}$ 
- Semua dinding nonstruktural dimodelkan sebagai beban merata garis, tegak lurus pada bidang lantai.

\section{HASIL ANALISIS}

Besarnya defleksi struktur dapat dilihat dari perpindahan titik (point displacement) tiap-tiap lantai menurut arah beban gempa (spektrum respons) yang ditinjau. Dalam penelitian ini ditinjau arah gempa menurut sumbu $\mathrm{X}$ dan sumbu $\mathrm{Y}$ di lantai 22 yang merupakan puncak struktur utama.

Analisis ini akan menampilkan besarnya perpindahan titik lateral maksimal, yaitu di salah satu titik terjauh dari CoR, dan selisih perpindahan titik lateral maksimal antara dua titik terjauh untuk mengetahui besarnya pengaruh torsi. Titik yang terjauh dari $\mathrm{CoR}$ yang ditinjau adalah titik 1 . Titik yang terjauh terhadap titik 1 adalah titik 399 (Gambar 21).

Perpindahan titik lateral maksimal di lantai 22 terhadap gempa arah sumbu X di titik 1 dan 399, ada di dalam Tabel 1, sedangkan terhadap gempa arah sumbu Y ada di dalam Tabel 2. Urutan besarnya defleksi lateral maksimal terhadap gempa arah sumbu $\mathrm{X}$ di titik 1 sebagai berikut: model eksisting $=12,67$ $\mathrm{cm}$; model eksperimen $2=12,16 \mathrm{~cm}$; model eksperimen $3=11,32 \mathrm{~cm}$; model eksperimen $1=9,65 \mathrm{~cm}$. Urutan besarnya defleksi lateral maksimal terhadap gempa arah sumbu Y di titik 1 sebagai berikut: model eksperimen $3=9,534 \mathrm{~cm}$; model eksperimen $1=$ $9,515 \mathrm{~cm}$; model eksperimen $2=8,8 \mathrm{~cm}$; pada model eksisting $=7,78 \mathrm{~cm}$.

Terhadap gempa arah sumbu $\mathrm{X}$, defleksi terbesar pada model eksisting, dan defleksi terkecil pada model eksperimen 1. Hasil ini menunjukkan bahwa terhadap gempa arah sumbu $\mathrm{X}$, model eksisting mempunyai kekakuan struktur terkecil dan model eksperimen 1 mempunyai kekakuan struktur terbesar. Terhadap gempa arah sumbu Y, defleksi terbesar pada model eksperimen 3, dan terkecil pada model eksisting. Hasil ini menunjukkan bahwa terhadap gempa arah sumbu Y, model eksisting mempunyai kekakuan struktur terbesar dan model eksperimen 3 mempunyai kekakuan struktur terkecil. Dengan pemahaman bahwa defleksi model eksisting (sumbu $\mathrm{X}$ dan Y) dirancang tidak melampaui defleksi yang diijinkan, maka besarnya defleksi maksimal model eksiting arah sumbu $X=12,67 \mathrm{~cm}$ dijadikan acuan. Dari table 2 terlihat defleksi semua model eksperimen arah sumbu Y tidak melampaui angka tersebut, sehingga dapat disimpulkan kekakuan semua model eksperimen pada arah sumbu Y masih didalam batas yang disyaratkan. Selisih defleksi di titik 1 dan di titik 399 menunjukkan besarnya pengaruh torsi, Tabel 1 memperlihatkan semua model eksperimen lebih baik dari model eksisting

\section{KONTROL DIMENSI KOLOM}

Karena penelitian ini bukan perancangan struktur, maka untuk mengontrol besarnya dimensi kolom, dipakai acuan besarnya momen dan gaya geser yang bekerja pada kolom-kolom kritis model eksisting. Besarnya momen dan gaya geser yang bekerja pada kolom-kolom kritis model eksisting tidak boleh dilampaui oleh besarnya momen dan gaya geser kritis model-model eksperimen. Kolom -1 (Gambar 21) dipilih sebagai kolom kritis yang ditampilkan. Tabel 3 dan Tabel 4 menampilkan besarnya momen dan gaya geser kolom -1 dari lantai 1 sampai dengan lantai 8 , dimana terdapat momen dan gaya geser paling signifikan.

Tabel 1. Defleksi Lateral Maksimal di Titik (1) Dan (399), pada Denah Lantai 22 Akibat Gempa Arah Sumbu X

\begin{tabular}{ccccccc}
\hline & & & Eksisting & Model 1 & Model 2 & Model 3 \\
\hline Storey & Point & Load & UX $(\mathbf{c m})$ & UX $(\mathbf{c m})$ & UX $(\mathbf{c m})$ & UX $(\mathbf{c m})$ \\
\hline 22 & 1 & SPECX & $\mathbf{1 2 . 6 7}$ & 9,65 & 12,16 & 11.32 \\
22 & 399 & SPECX & 5,52 & 8,15 & 7,7 & 8,19 \\
Selisih defleksi & & & $\mathbf{7 , 1 5}$ & 1,5 & 4,46 & 3,13 \\
\hline
\end{tabular}

Catatan:

SPECX $=$ Spektrum respon arah sumbu X

UX = Defleksi lateral arah sumbu $\mathrm{X}$, dalam $\mathrm{cm}$

Tabel 2. Defleksi Lateral Maksimal di Titik (1) dan (399), pada Denah Lantai 22 Akibat Gempa Arah Sumbu Y

\begin{tabular}{ccccccc}
\hline & & & Eksisting & Model 1 & Model 2 & Model 3 \\
\hline Storey & Point & Load & UY (cm) & UY (cm) & UY (cm) & UY (cm) \\
\hline 22 & 1 & SPEC90 & 7,78 & 9,51 & 8,8 & $\mathbf{9 , 5 3}$ \\
22 & 399 & SPEC90 & 7,78 & 9,53 & 8,7 & 9,55 \\
Selisih defleksi & & & 0 & $\mathbf{- 0 , 0 2}$ & $-0,1$ & $\mathbf{- 0 , 0 2}$ \\
\hline
\end{tabular}

Catatan:

SPEC90 = Spektrum Respon arah sumbu Y

UY = Defleksi lateral arah sumbu $\mathrm{Y}$, dalam $\mathrm{cm}$ 
Hasil analisis memperlihatkan bahwa terhadap gempa arah sumbu $\mathrm{X}$, besarnya momen dan gaya geser maksimal kolom pada model eksperimen 1 dan model eksperimen 3 di kolom-1, lebih kecil dibandingkan dengan yang bekerja di model eksisting, sedangkan pada model eksperimen 2 besarnya momen maksimal dilantai 5 dan gaya geser maksimal di lantai 7 lebih besar dari yang bekerja di model eksisting (dalam tabel 3 terlihat pada angka-angka yang di bolt). Terhadap gempa arah sumbu Y, besarnya momen dan gaya geser maksimal kolom-1 pada semua model-model eksperimen menunjukkan nilai yang lebih besar daripada yang bekerja di model eksisting (dalam tabel 4 terlihat pada angka-angka yang di bolt). Hal ini disebabkan pada arah sumbu Y, dinding cantilever core model eksisting dimensinya lebih besar/lebar dibandingkan dengan model-model eksperimen 1, 2 dan 3 sehingga menghasilkan kekakuan lebih besar. Namun momen (Mx) dan gaya geser (Vy) akibat gempa arah sumbu Y pada model- model eksperimen tidak melampaui momen dan gaya geser maksimal model eksisting pada arah sumbu X (dapat dilihat perbandingannya dalam Tabel 3 dan Tabel 4). Karena penampang melintang kolom dirancang simetri ke semua arah (Gambar 22), maka dapat disimpulkan bahwa kapasitas kolom-kolom eksisting tidak dilampaui oleh momen dan gaya-gaya geser model-model eksperimen. Model yang memiliki kinerja struktural terbaik adalah model eksperimen 1, disusul model eksperimen 3. Sedangkan model eksperimen 2 tidak lebih baik dari model eksisiting. Dalam hal kekakuan, model eksperimen 2 lebih baik dari model eksisting, tapi momen dan gaya geser maksimal di kolom-1 model eksperimen 2 lebih besar dari yang terjadi pada model eksisting. Perlu dilakukan penelitian lanjut untuk mengetahui apakah penambahan kekuatan kolom-kolom podium model eksperimen 2 perlu merubah dimensi penampangnya atau tidak.

Tabel 3. Momen Maksimal dan Gaya Geser Maksimal pada Kolom (1) di Lantai 1 s/d Lantai 8 Terhadap Gempa Arah Sumbu X

\begin{tabular}{|c|c|c|c|c|}
\hline & Model Eksisting & Model Eksperimen 1 & Model Eksperimen 2 & Model Eksperimen 3 \\
\hline Momen maksimal kolom (1) - lantai 8 & $11.303 .688 \mathrm{kgf} \mathrm{cm}$ & $8.277 .15 \mathrm{kgf} \mathrm{cm}$ & $11.029 .441 \mathrm{kgf} \mathrm{cm}$ & $9.747 .973 \mathrm{kgf} \mathrm{cm}$ \\
\hline Momen maksimal kolom (1) - lantai 7 & $9.760 .684 \mathrm{kgf} \mathrm{cm}$ & 7.908.428 kgf cm & $10.775 .484 \mathrm{kgf} \mathrm{cm}$ & $9.453 .449 \mathrm{kgf} \mathrm{cm}$ \\
\hline Momen maksimal kolom (1) - lantai 6 & $14.903 .97 \mathrm{kgf} \mathrm{cm}$ & $10.444 .607 \mathrm{kgf} \mathrm{cm}$ & 14.871.722 kgf cm & $13.789 .679 \mathrm{kgf} \mathrm{cm}$ \\
\hline Momen maksimal kolom (1) - lantai 5 & 15.274.904 kgf cm & $10.718 .420 \mathrm{kgf} \mathrm{cm}$ & $15.384 .526 \mathrm{kgf} \mathrm{cm}$ & 14.184.791 kgf cm \\
\hline Momen maksimal kolom (1) - lantai 4 & $9.151 .884 \mathrm{kgf} \mathrm{cm}$ & $6.697 .110 \mathrm{kgf} \mathrm{cm}$ & 9.268.223 kgf cm & 8.559.396 kgf cm \\
\hline Momen maksimal kolom (1) - lantai 3 & $5.808 .331 \mathrm{kgf} \mathrm{cm}$ & $4.759 .592 \mathrm{kgf} \mathrm{cm}$ & $6.562 .083 \mathrm{kgf} \mathrm{cm}$ & $6.079 .934 \mathrm{kgf} \mathrm{cm}$ \\
\hline Momen maksimal kolom (1) - lantai 2 & $11.780 .438 \mathrm{kgf} \mathrm{cm}$ & $7.628 .186 \mathrm{kgf} \mathrm{cm}$ & $11.238 .702 \mathrm{kgf} \mathrm{cm}$ & $10.021 .264 \mathrm{kgf} \mathrm{cm}$ \\
\hline Momen maksimal kolom (1) - lantai 1 & $12.582 .160 \mathrm{kgf} \mathrm{cm}$ & $8.611 .981 \mathrm{kgf} \mathrm{cm}$ & $12.817 .55 \mathrm{kgf} \mathrm{cm}$ & $11.200 .798 \mathrm{kgf} \mathrm{cm}$ \\
\hline Gaya geser maksimal kolom (1) - lantai 8 & $\mathbf{5 8 . 1 1 6} \mathrm{kgf}$ & $42.833 \mathrm{kgf}$ & $57.690 \mathrm{kgf}$ & $51.316 \mathrm{kgf}$ \\
\hline Gaya geser maksimal kolom (1) - lantai 7 & $54.302 \mathrm{kgf}$ & 43.055 kgf & $59.918 \mathrm{kgf}$ & $53.366 \mathrm{kgf}$ \\
\hline Gaya geser maksimal kolom (1) - lantai 6 & $51.665 \mathrm{kgf}$ & $35.646 \mathrm{kgf}$ & $51.595 \mathrm{kgf}$ & $47.808 \mathrm{kgf}$ \\
\hline Gaya geser maksimal kolom (1) - lantai 5 & $49.252 \mathrm{kgf}$ & $34.345 \mathrm{kgf}$ & $49.874 \mathrm{kgf}$ & $46.017 \mathrm{kgf}$ \\
\hline Gaya geser maksimal kolom (1) - lantai 4 & $43.835 \mathrm{kgf}$ & $32.056 \mathrm{kgf}$ & $45.916 \mathrm{kgf}$ & $41.695 \mathrm{kgf}$ \\
\hline Gaya geser maksimal kolom (1) - lantai 3 & $13.447 \mathrm{kgf}$ & $10.966 \mathrm{kgf}$ & $15.464 \mathrm{kgf}$ & $13.990 \mathrm{kgf}$ \\
\hline Gaya geser maksimal kolom (1) - lantai 2 & $26.838 \mathrm{kgf}$ & $15.987 \mathrm{kgf}$ & $23.991 \mathrm{kgf}$ & $20.965 \mathrm{kgf}$ \\
\hline Gaya geser maksimal kolom (1) - lantai 1 & $32.533 \mathrm{kgf}$ & $22.450 \mathrm{kgf}$ & $33.954 \mathrm{kgf}$ & $29.278 \mathrm{kgf}$ \\
\hline
\end{tabular}

Tabel 4. Momen Maksimal dan Gaya Geser Maksimal pada Kolom (1) di Lantai 1 s/ Lantai 8 Terhadap Gempa Arah Sumbu Y

\begin{tabular}{|c|c|c|c|c|}
\hline & Model Eksisting & Model Eksperimen 1 & Model Eksperimen 2 & Model Eksperimen 3 \\
\hline Momen maksimal kolom (1) - lantai 8 & $2.441 .690 \mathrm{kgf} \mathrm{cm}$ & $2.377 .288 \mathrm{kgf} \mathrm{cm}$ & $3.389 .053 \mathrm{kgf} \mathrm{cm}$ & $2.904 .688 \mathrm{kgf} \mathrm{cm}$ \\
\hline Momen maksimal kolom (1) - lantai 7 & $1.533 .733 \mathrm{kgf} \mathrm{cm}$ & 1.606.714 $\mathrm{kgf} \mathrm{cm}$ & $2.591 .107 \mathrm{kgf} \mathrm{cm}$ & $2.188 .983 \mathrm{kgf} \mathrm{cm}$ \\
\hline Momen maksimal kolom (1) - lantai 6 & $1.053 .103 \mathrm{kgf} \mathrm{cm}$ & 1.402 .275 & $2.480 .851 \mathrm{kgf} \mathrm{cm}$ & $2.411 .890 \mathrm{kgf} \mathrm{cm}$ \\
\hline Momen maksimal kolom (1) - lantai 5 & $1.534 .596 \mathrm{kgf} \mathrm{cm}$ & 1.700 .532 & $3.108 .391 \mathrm{kgf} \mathrm{cm}$ & 2.734.564 kgf cm \\
\hline Momen maksimal kolom (1) - lantai 4 & 4.012.579 $\mathrm{kgf} \mathrm{cm}$ & 4.409.537 $\mathrm{kgf} \mathrm{cm}$ & $5.476 .793 \mathrm{kgf} \mathrm{cm}$ & 4.989.743 $\mathrm{kgf} \mathrm{cm}$ \\
\hline Momen maksimal kolom (1) - lantai 3 & $3.198 .370 \mathrm{kgf} \mathrm{cm}$ & 4.179.057 $\mathrm{kgf} \mathrm{cm}$ & $5.092 .309 \mathrm{kgf} \mathrm{cm}$ & $4.743 .445 \mathrm{kgf} \mathrm{cm}$ \\
\hline Momen maksimal kolom (1) - lantai 2 & $821.747 \mathrm{kgf} \mathrm{cm}$ & $1.033 .559 \mathrm{kgf} \mathrm{cm}$ & 2.658.304 kgf cm & $1.766 .042 \mathrm{kgf} \mathrm{cm}$ \\
\hline Momen maksimal kolom (1) - lantai 1 & $530.522 \mathrm{kgf} \mathrm{cm}$ & $1.905 .203 \mathrm{kgf} \mathrm{cm}$ & $1.863 .119 \mathrm{kgf} \mathrm{cm}$ & $2.655 .956 \mathrm{kgf} \mathrm{cm}$ \\
\hline Gaya geser maksimal kolom (1) - lantai 8 & $12.650 \mathrm{kgf}$ & $12.486 \mathrm{kgf}$ & $17.593 \mathrm{kgf}$ & $15.156 \mathrm{kgf}$ \\
\hline Gaya geser maksimal kolom (1) - lantai 7 & $9.138 \mathrm{kgf}$ & $9.903 \mathrm{kgf}$ & $15.389 \mathrm{kgf}$ & $13.060 \mathrm{kgf}$ \\
\hline Gaya geser maksimal kolom (1) - lantai 6 & $3.642 \mathrm{kgf}$ & $4.832 \mathrm{kgf}$ & $8.434 \mathrm{kgf}$ & $8.301 \mathrm{kgf}$ \\
\hline Gaya geser maksimal kolom (1) - lantai 5 & $4.444 \mathrm{kgf}$ & $5.085 \mathrm{kgf}$ & $9.171 \mathrm{kgf}$ & $8.412 \mathrm{kgf}$ \\
\hline Gaya geser maksimal kolom (1) - lantai 4 & 13.237 kgf & $13.216 \mathrm{kgf}$ & $17.829 \mathrm{kgf}$ & $15.411 \mathrm{kgf}$ \\
\hline Gaya geser maksimal kolom (1) - lantai 3 & $12.671 \mathrm{kgf}$ & $17.890 \mathrm{kgf}$ & $20.666 \mathrm{kgf}$ & $\mathbf{1 9 . 9 5 5} \mathrm{kgf}$ \\
\hline Gaya geser maksimal kolom (1) - lantai 2 & $5.955 \mathrm{kgf}$ & $6.057 \mathrm{kgf}$ & $8.480 \mathrm{kgf}$ & $7.212 \mathrm{kgf}$ \\
\hline Gaya geser maksimal kolom (1) - lantai 1 & $1.332 \mathrm{kgf}$ & $4.673 \mathrm{kgf}$ & $4.770 \mathrm{kgf}$ & $6.744 \mathrm{kgf}$ \\
\hline
\end{tabular}

Tebal dinding cantilever core 1 model eksisting lihat Gambar 23, eksperimen $2=40 \mathrm{~cm}$

Tebal dinding cantilever core 2 semua model eksperimen $=40 \mathrm{~cm}$, dinding toilet model eksperimen $1=15 \mathrm{~cm}$, dinding shaft model eksperimen 1,2 dan $3=15 \mathrm{~cm}$

Tebal dinding cantilever core 3 semua model eksperimen $=40 \mathrm{~cm}$ 


\section{KESIMPULAN KETERPADUAN}

Pengaruh pemindahan cantilever core terhadap keterpaduan perancangan arsitektur (Tabel 5):

Tabel 5. Kesimpulan Pengaruh Penataan Struktur Terhadap Keterpaduan

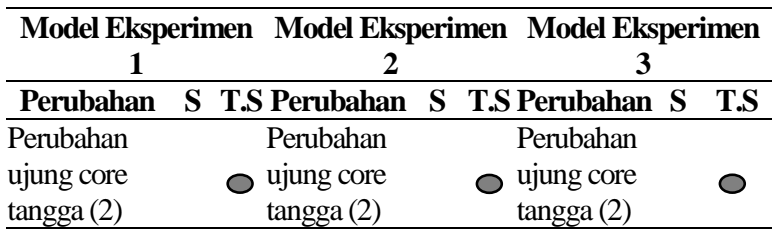

Perubahan

dinding toilet

menjadi

cantilever

core,

\begin{tabular}{|c|c|c|c|c|}
\hline - & $\begin{array}{l}\text { Perubahan } \\
\text { tebal din- } \\
\text { ding core } \\
\text { tangga (3), } \\
\text { tidak } \\
\text { signifikan }\end{array}$ & 0 & $\begin{array}{l}\text { Perubahan } \\
\text { tebal din- } \\
\text { ding core } \\
\text { tangga (3), } \\
\text { tidak } \\
\text { signifikan }\end{array}$ & 0 \\
\hline - & $\begin{array}{l}\text { Kejujuran } \\
\text { tampilan } \\
\text { struktur } \\
\text { pada core } \\
\text { lift (1) }\end{array}$ & 0 & $\begin{array}{l}\text { Kejujuran } \\
\text { tampilan } \\
\text { struktur } \\
\text { pada core } \\
\text { lift (1) }\end{array}$ & 0 \\
\hline
\end{tabular}

\section{REKOMENDASI}

1. Hasil penelitian ini memperlihatkan bahwa perancang struktur dapat memanfaatkan penataan elemen struktural untuk mengendalikan perilaku dinamik struktur terhadap gempa. Dengan penataan elemen struktural yang tepat, keterpaduan dengan rancangan arsitektur bisa sangat optimal.

2. Bagi para arsitek, hasil penelitian ini memperlihatkan bahwa arsitek mempunyai keleluasaan untuk berkreasi pada saat merancang bangunan tinggi sampai dengan ketinggian sekitar 27 lantai, selama kerjasama arsitek dengan perancang struktur dilakukan secara kontinyu, dengan baik dan terpadu sejak penyusunan rancangan skematik.
3. Penelitian ini dapat dilanjutkan dengan penelitian:

a. Kekuatan elemen-elemen struktural dari modelmodel eksperimen.

b. Tingkat efisiensi penggunaan material akibat perubahan tata letak elemen struktural.

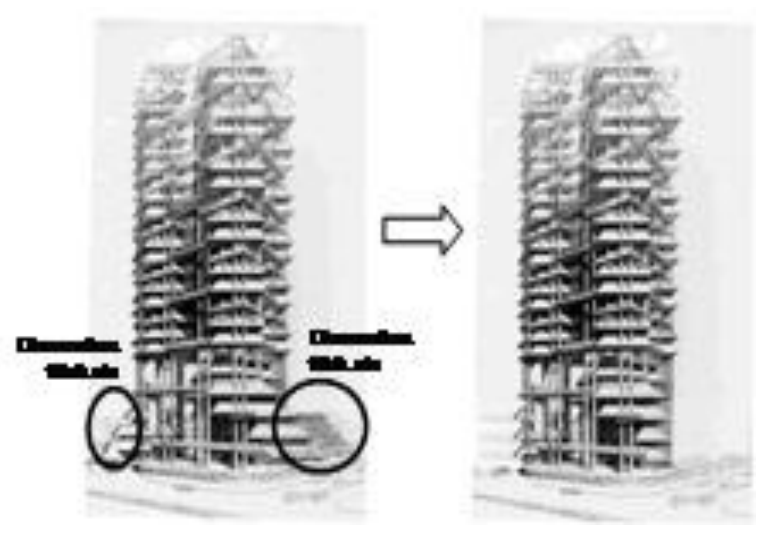

Gambar 1. Asumsi Penyederhanaan Bentuk Tower

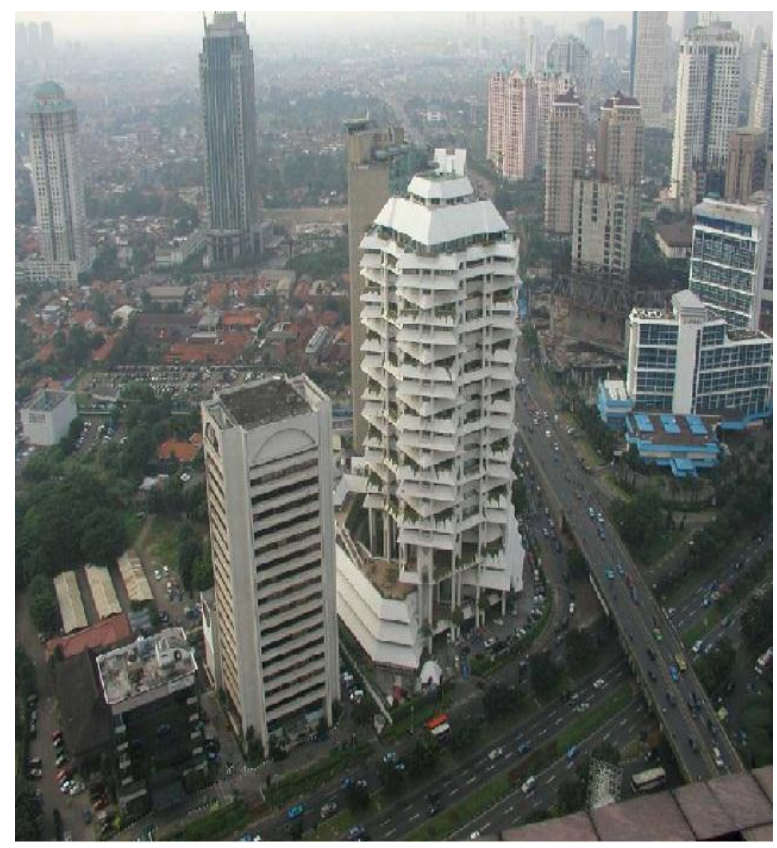

Sumber: Company Profile PT Intiland

Gambar 2. GITJ dalam lingkungan 


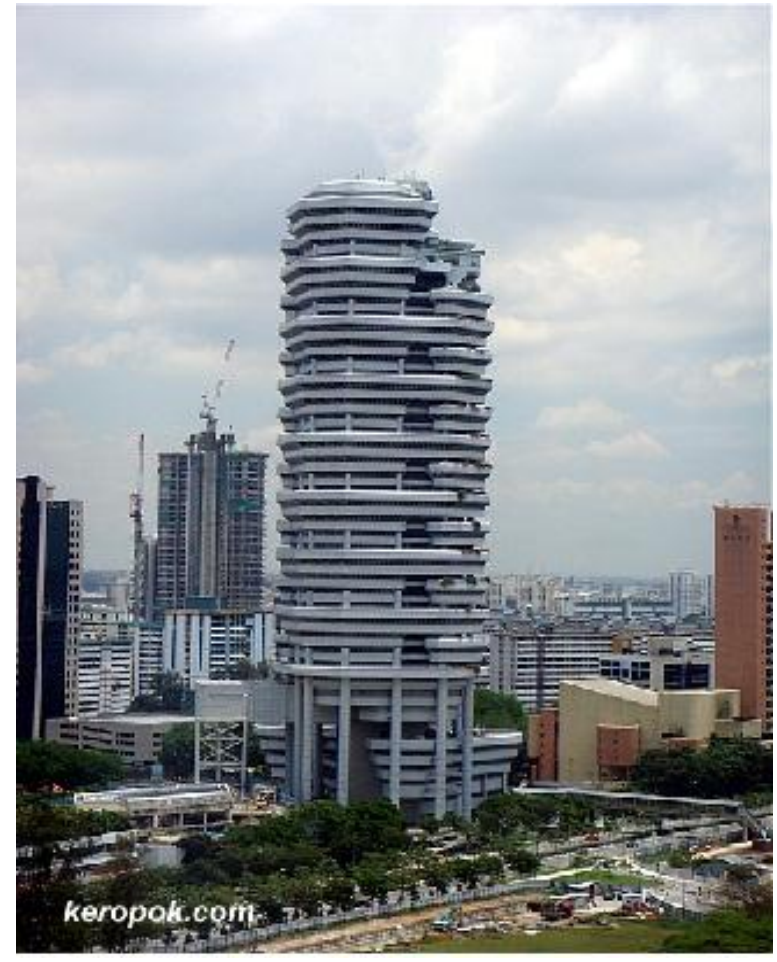

Gambar 3. CBS dalam lingkungan.

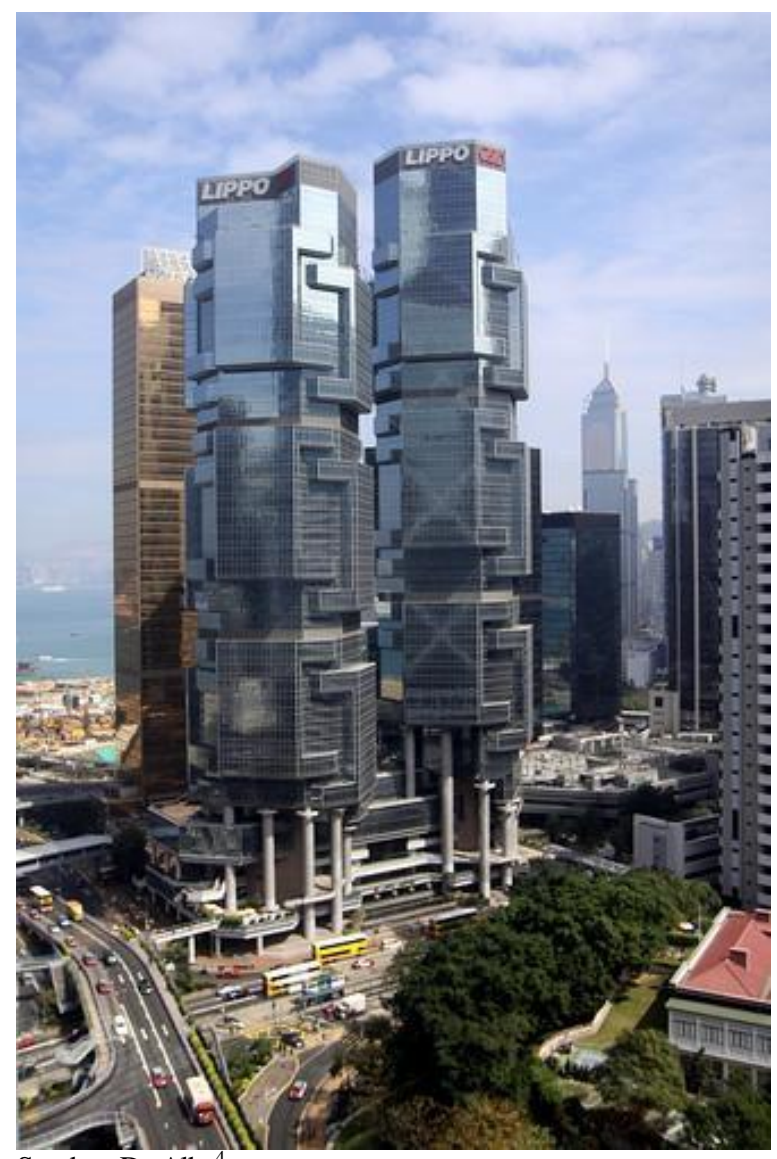

Sumber: De Alba ${ }^{4}$

Gambar 4. BCH dalam lingkungan

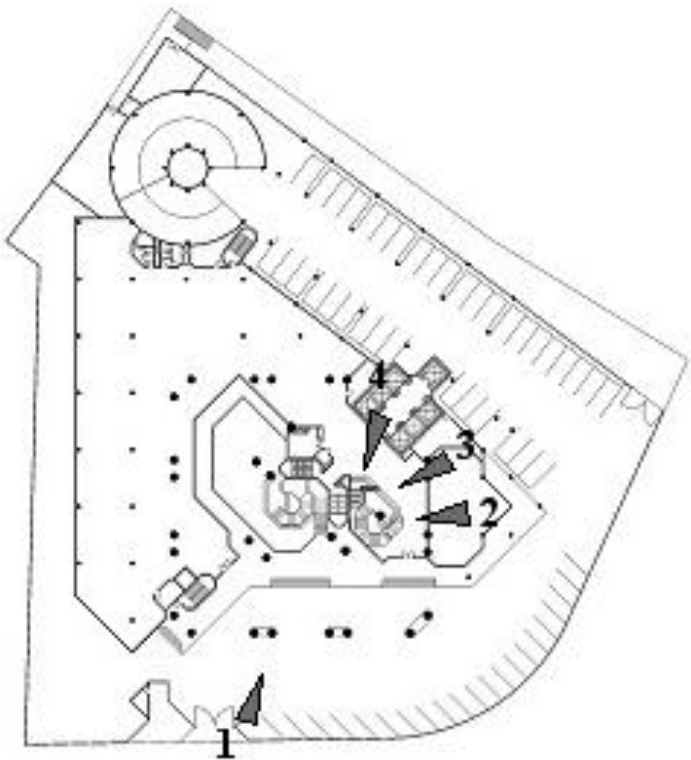

Gambar 5. Denah Lantai Dasar GIT
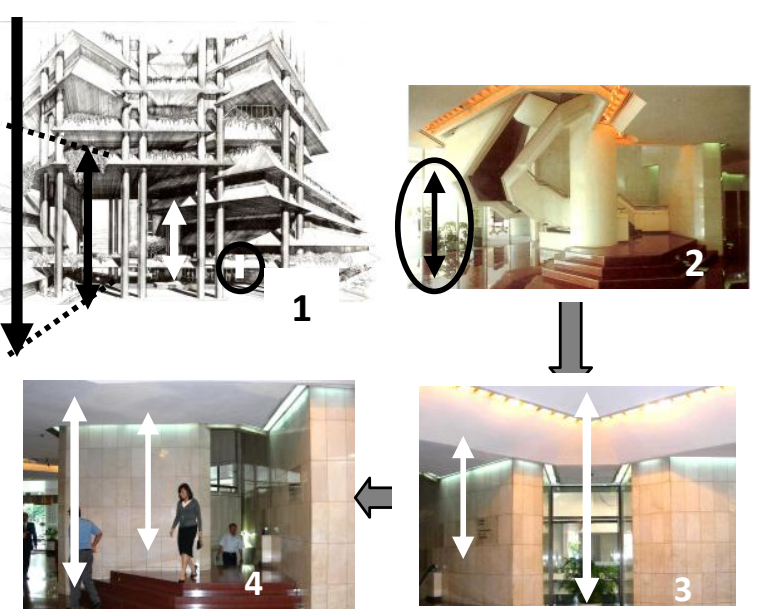

Sumber: Majalah Mimar 30, Desember 1988

Gambar 6. Skala Ruang, Hirarki dari Hall Eksterior ke Hall Interior.

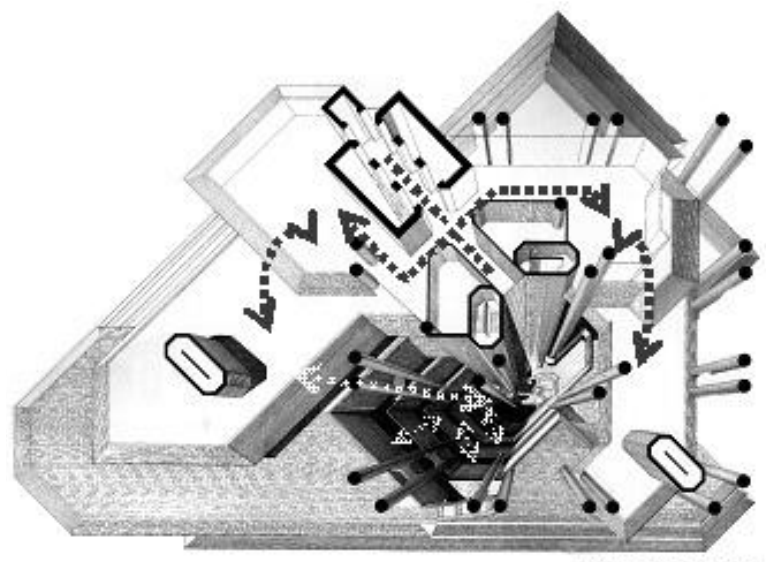

Sumber: De $\mathrm{Alba}^{4}$

Gambar 7. Spatial Interpenetration pada Lantai-lantai Di bawah Lantai-lantai Tipikal 

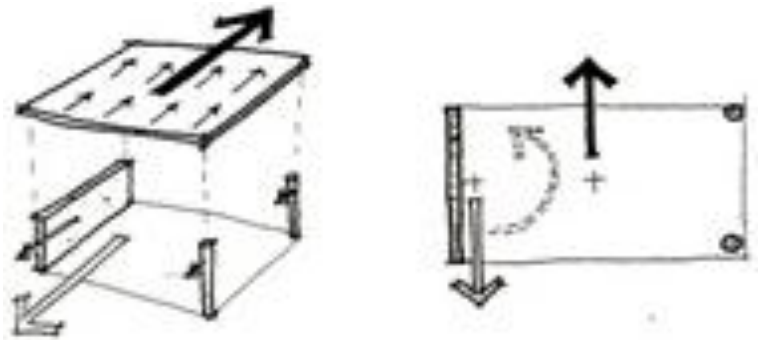

Sumber: Arnold, C (1982)

Gambar 8. Prinsip Terjadinya Torsi

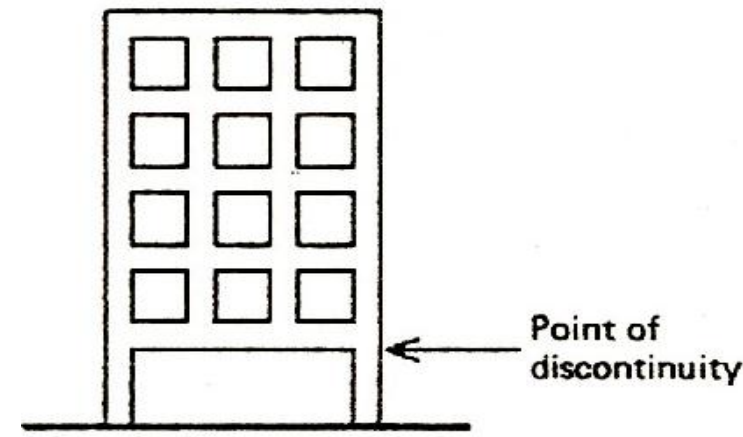

Sumber: Arnold, C (1982)

Gambar 9. Titik diskontinuitas, torsi
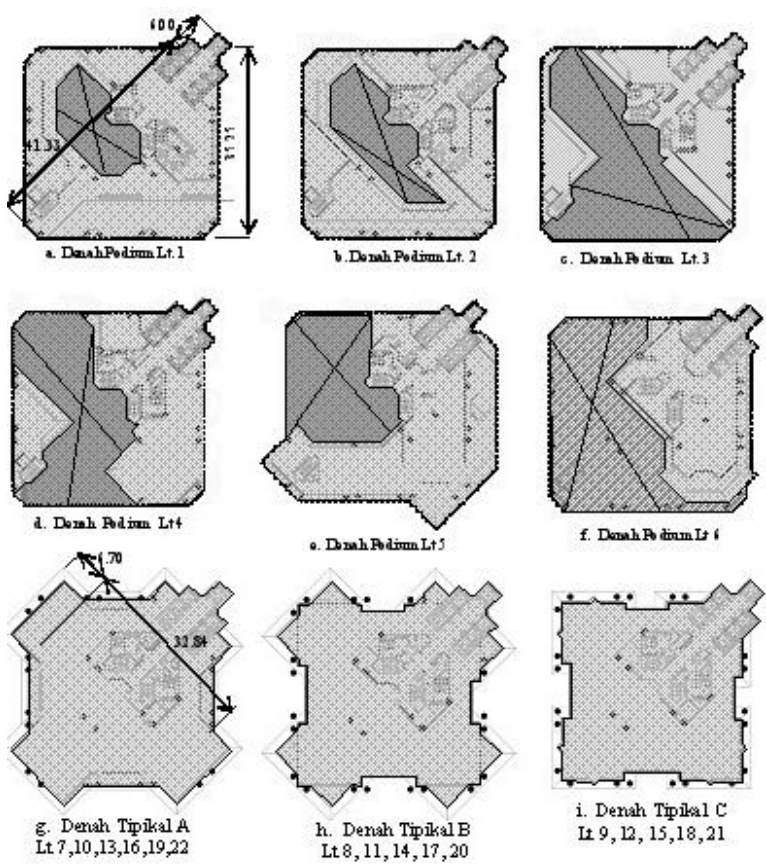

Gambar 10. Bentuk Denah Lantai-lantai Podium dan Tipikal
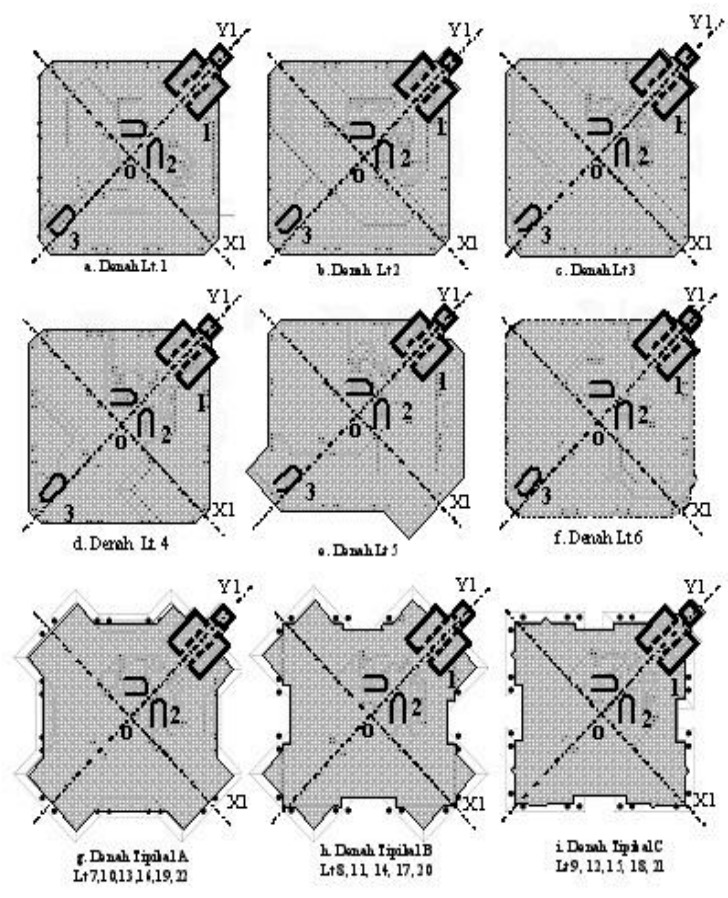

Catatan: Koordinat $0=(+3154,+2491) \mathrm{cm}$ teih adap smbu utsma (XYY).

Gambar 11. Posisi Cantilever Core

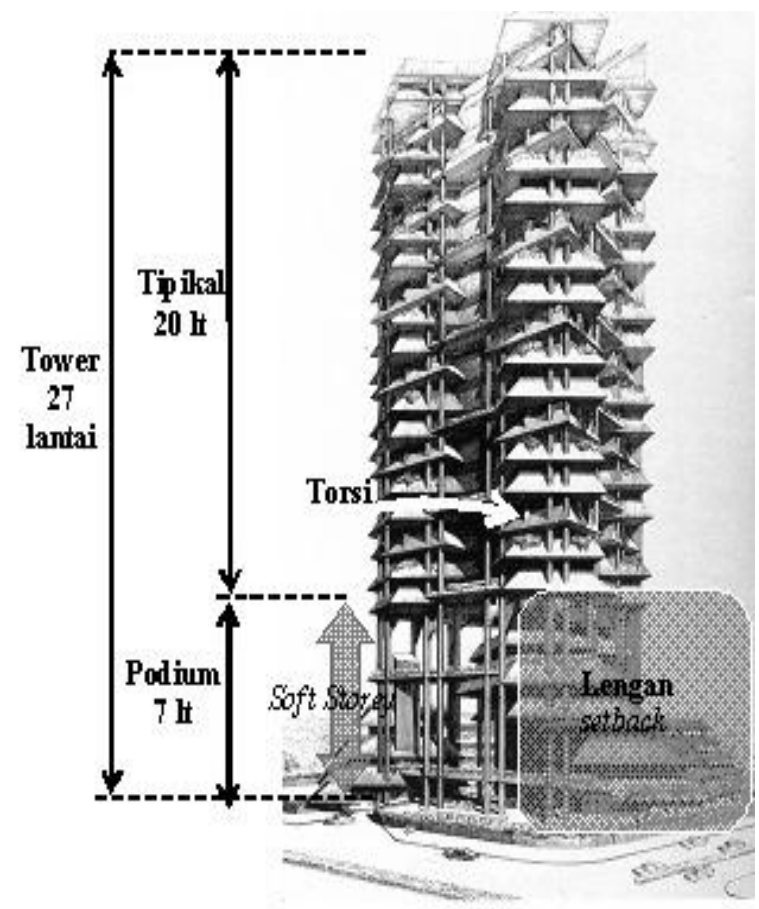

Gambar 12. Perspektif Eksterior GITJ Perilaku Torsi dan Setback 


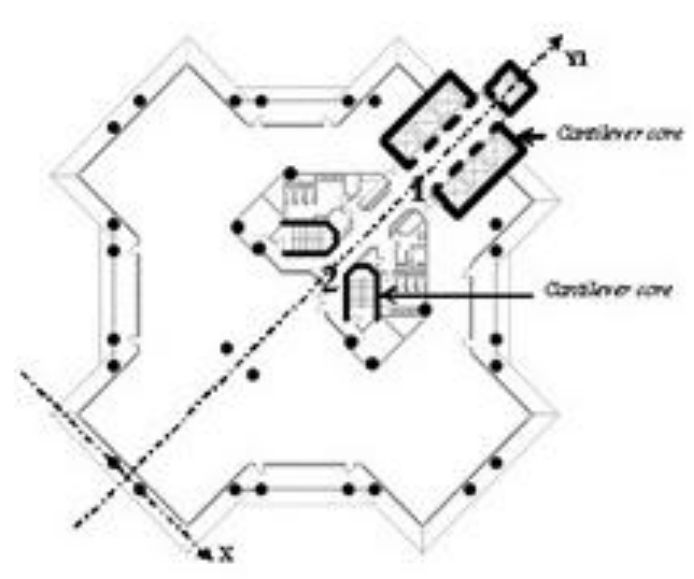

Gambar 13. Model Eksisting-Tipikal

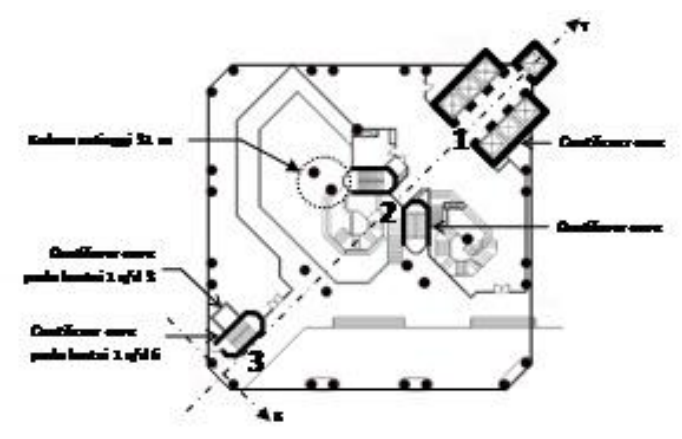

Gambar 14. Model Eksisting - Podium Lantai 1

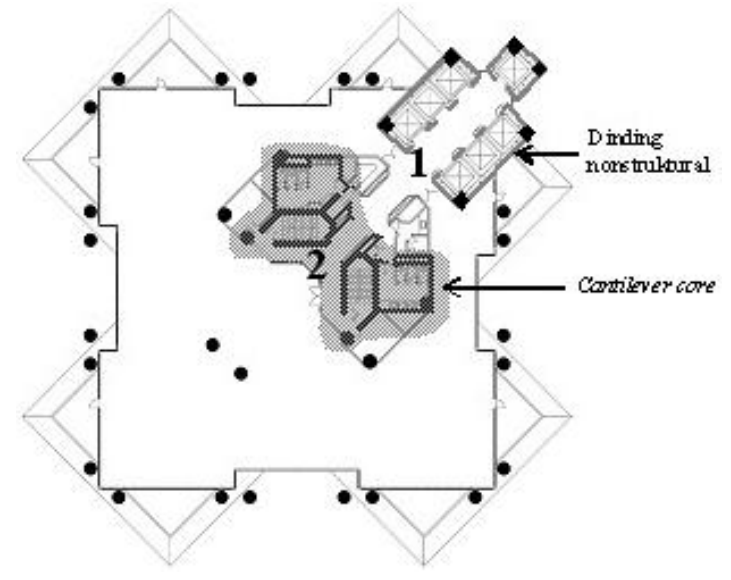

Gambar 15. Model Eksperimen 1-Tipikal

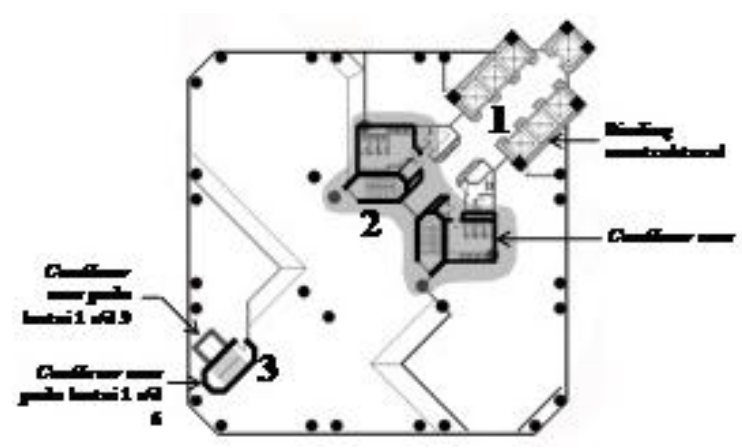

Gambar 16. Model Eksperimen 1- Podium

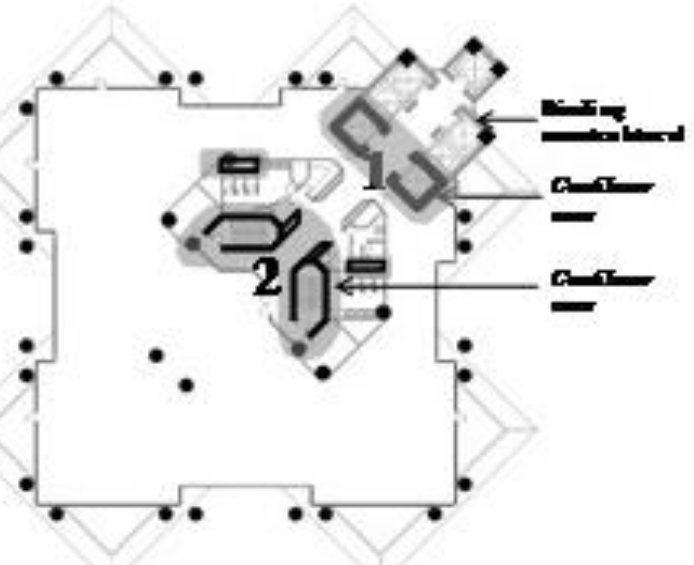

Gambar 17. Model Eksperimen 2 - Tipikal

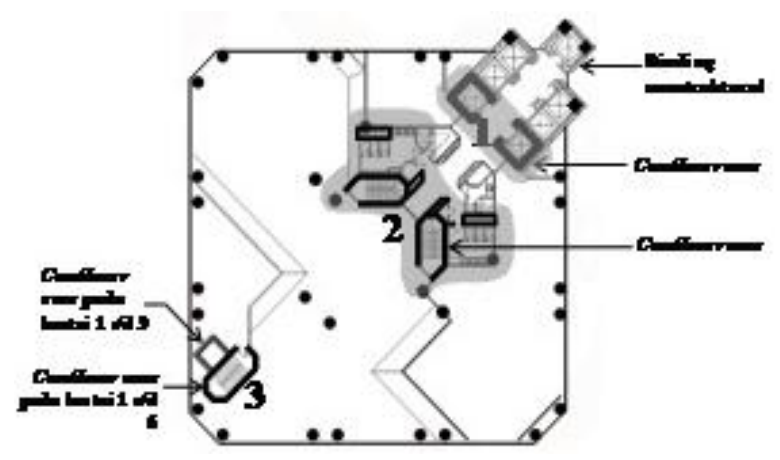

Gambar 18. Model Eksperimen 2 -Podium

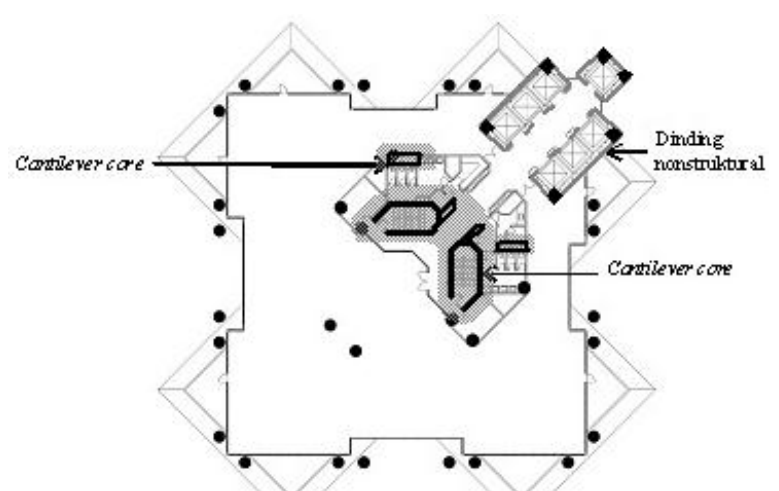

Gambar 19. Model Eksperimen 3- Tipikal

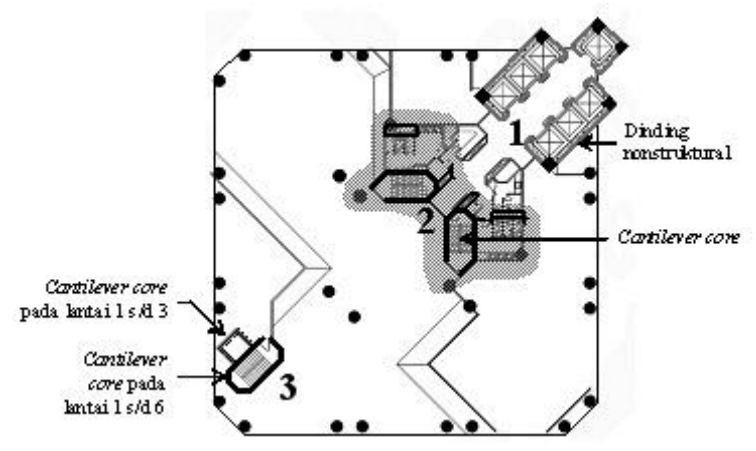

Gambar 20. Model Eksperimen 3- Podium 


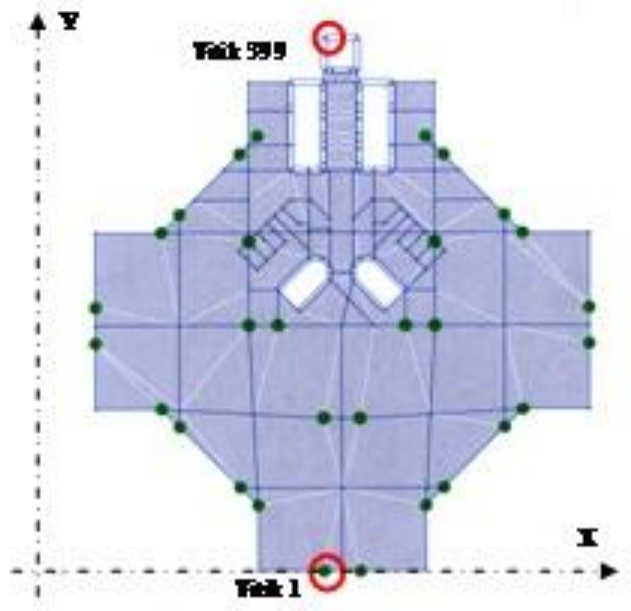

Gambar 21. Peta Titik Perpindahan Lateral yang Ditinjau, Titik 1 dan 399, Lantai 22

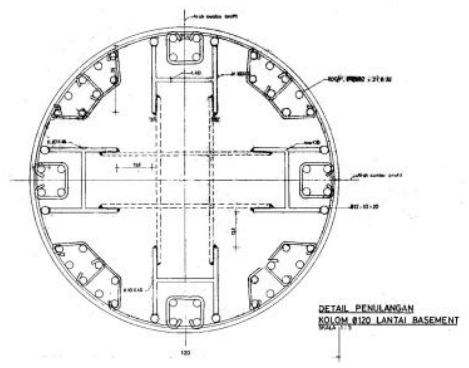

Sumber: As-build Drawing, Wiratman \& Associate (1983)

Gambar 22. Penampang Kolom Komposit Podium.

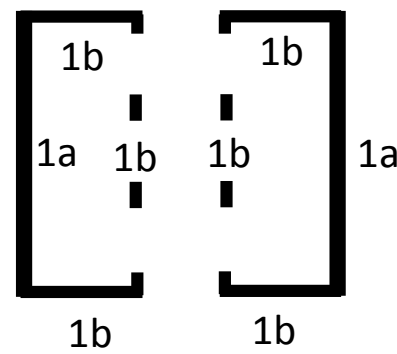

Tebal dinding core:

$1 \mathrm{a}=65 \mathrm{~cm}$

$1 \mathrm{~b}=60 \mathrm{~cm}$

Gambar 23. Denah Core Cantilever 1 Model Eksisting

\section{DAFTAR PUSTAKA}

Arnold, C. (1982). Building configuration and seismic design. John Wiley \& Sons.

Badan Standard Nasional-BSN. Standar Perencanaan Ketahanan Gempa untuk Struktur Bangunan Gedung. SNI 03-1726-2002.

Charleson, A. (2008). Seismic Design for Architecture. Elsevier Ltd. Computers \& Structures Inc. Berkely. ETABS v. 9.05.

De Alba, R. (2003). Paul Rudolph the Late Work. Princeton Architectural Press.

Laurens, M. J. (2004). Arsitektur dan Perilaku Manusia. Penerbit PT. Grasindo, Jakarta.

Meiss, P.V. (1994). Elements of Architecture from form to place. E \& FN Spon

Wangsadinata, W. (1986). Peranan Arsitektur dan Struktur dalam Perencanaan BangunanBangunan Tinggi. Fakultas Teknik Sipil dan Prencanaan Universitas Trisakti.

Warfield, J.P. (ed) (1983). Paul Rudolph 1983-1984 Recipient of the Plym Distinguished Professorship. School of Architecture University of Illinois at Urbana-Champaign. 